\title{
PREMISES AND EFFECTS OF CHINESE M\&AS ON THE EUROPEAN MARKET IN THE ENERGY SECTOR
}

\section{Łopacińska, $\mathrm{K}$.}

Mergers and acquisitions (M\&As) play an increasingly important role in the expansion of Chinese companies in the European market. The article aims to analyze the largest, in terms of value, M\&As conducted by Chinese companies between 2005 and 2015 in the energy sector, in order to present the main premises and consequences of such agreements. For this purpose, the assessment was made based on case studies conducted by the Author, as well as the opinions of experts specializing in the business models of Chinese enterprises, derived from qualitative interviews. Specialized literature on the discussed forms of international expansion of Chinese enterprises was also used. Based on the case study method, analysis of the agreements shows that decisions on conducting M\&As are strongly influenced by the adopted strategic directions of the companies' development, their desire to develop a competitive position on the market and improve their financial condition. The effects, in turn, were addressed, taking into account the dimensions of the strategic and tactical importance for companies.

Keywords: mergers and acquisitions; Chinese companies; European market; energy sector JEL Classification: F53, L1, L2.

\section{Introduction and Theoretical Background}

Mergers and acquisitions play an increasingly important role in the expansion of Chinese companies into the European market. Europe has become a promising direction for the location of investments, especially after the global financial crisis of 2007-2009; the economic downturn resulted in the inclination to seek new sources of financing in the economy and the market. According to a report by ING Corporate Finance Asia, China maintains a strong trend for undertaking mergers and acquisitions in Europe. This is evidenced by the results achieved by Chinese investors in the first half of 2015. During this period, Chinese companies established as many as 56 agreements in the form of mergers and acquisitions, with a total value equal to 15.6 billion USD, showing an impressive, $30.2 \%$ increase in quantity and $13 \%$ growth in value of the undertaken projects, compared to the first half of 2014, when they concluded a total of 43 contracts with a total value of 13.8 billion USD. This impressive upward trend is further indicated by reference to the corresponding period of 2013, when there were only 27 contracts conducted with a total value of 5 billion USD (ING Report, 2014; ING Report, 2015).

Conducting mergers and acquisitions in the highly-developed European countries corresponds to the goals of the Chinese government's plans related to economic expansion abroad, including Europe. The results of the mergers and acquisitions are diverse, as are the sectors in which the companies operate.

An earlier version of this paper was presented at the 17th International Joint Conference: Central and Eastern Europe in the Changing Business Environment at the University of Economics, Prague. 
The issue of international mergers and acquisitions taken in literature, focuses mainly on identification of the sources of their success. Sudarsanam $(1995 ; 2003)$ presents a broad spectrum of contemporary challenges and issues, as well as a comprehensive review of mergers and acquisition concepts and techniques, as well as their implementation in various market conditions.

The author points to an international and multidisciplinary research perspective focused on mergers and acquisitions, conducted both in the European and US markets. Weston $(1990 ; 1992)$, in turn, has presented the principles the use of which is essential for the success of mergers and acquisitions. Sherman A. J. (Sherman \& Hart, 2010) presented the whole process associated with conducting such agreements and its consequences, examining each stage of this process by analyzing cases of mergers and acquisitions on the example of selected companies. Hopkins (1999) and Gonzalez et al. (1998) focus on exploring international mergers and acquisitions, specifically on the strategic importance of these agreements and the integration strategy after the agreement is reached. In their research, the authors take into account the financial and economic grounds influencing the direction and scale of integration. In literature (Gallo, 2011), there is also a comparative analysis of Chinese and Western styles of management, to highlight the challenges the investors engaging with companies from other cultural circles face. In particular, the importance of matching the Western business practices with Chinese wisdom is emphasized as a prerequisite for the success of projects based on a merger and acquisition agreement. In addition, the influence of Chinese culture - especially Chinese values and traditions - on the development of foreign direct investments, such as joint ventures, as well as the management styles, theories and organizational behavior of Chinese enterprises (Alon et al., 2008) are examined.

The analysis shows that in many countries in the world that are transforming their economies, mergers and acquisitions are regarded as important tools for economic development and competitiveness creation.

Moreover, it should be emphasized that the issue taken in this article is rooted in international business theories, mainly in Dunning's (1980) international production theory, Ricard's (2006) comparative advantage theory, and Porter's $(1985 ; 2008 ; 2010)$ theory of competitive advantage.

\section{Methodology}

The purpose of the research and analysis undertaken in the article is to identify the premises and the effects of the largest M\&A investments in terms of value that Chinese companies conducted in the European market, in the energy sector during the period of 2005-2015.

The assessment of the development of mergers and acquisitions in the European market was made based on case studies conducted by the Author; these included agreements between such companies as: China National Petroleum Corporation and Eni Spa, China Three Gorges Corporation and Energias de Portugal SA, China Huaneng Group Corporation and InterGen NV, Sinochem Corporation and Emerald Energy and China Investment Corp and Gas de France Suez, as well as the opinions of experts specializing in the business models of Chinese enterprises, derived from qualitative interviews.

The interviews with experts covered the following issues: 
- The importance of market conditions and their impact on the tendency of companies to merge;

- Evaluation of the activity of Chinese companies on foreign markets, including their activity on the European market over the past ten years (defining the dominant forms of this expansion and the sectors of greatest interest);

- Assessing the role that mergers and acquisitions play among the dominant forms of expansion of Chinese companies in the European market;

- An attempt to assess the impact of mergers and acquisitions conducted by Chinese companies on the European market from the point of view of their impact on the market forces;

- Identification of the main success and failure factors of M\&As between Chinese and European companies;

- Identification of development perspectives of corporations with Chinese capital that are the result of mergers and acquisitions on the European market.

In the evaluation process, specialized literature on the discussed forms of international expansion of Chinese enterprises was also used.

\section{Results}

Development of the energy sector has been the goal of the Chinese government for nearly 70 years. Over the past 10 years, the energy sector has played a key role in stimulating the development of the Chinese economy and improving the population's standard of living.

This was possible thanks to the dynamic growth of domestic production and consumption of energy since 1980 . It should be noted that about $80 \%$ of the generated power in the Middle Kingdom comes from fossil sources, 17\% from water systems, and only $2 \%$ comes from nuclear energy, mainly from plants located in Guangdong and Zhejiang (World Nuclear Association, 2016). This means that despite a large energy potential, a significant part of it still needs development.

This policy resulted in the use of the cheapest suppliers of energy resources, which meant that since 2006, China has become the largest emitter of carbon dioxide and greenhouse gases in the world (Brahic, 2007; Reuters, 2006). Now, however, ecological and climatic challenges are forcing the companies to take action to protect the environment, which significantly affects the development of the Chinese energy sector.

At the same time, it should be emphasized that China became the first developing country which, in 2007, formulated and published a strategy for action for climate change in the conditions of global warming (Andrews-Speed et al., 2014; Xinhuanet News, 2007). Part of this strategy planned, in the Twelfth Five-Year Plan (2011-2015), control of greenhouse gas emissions by setting the targets to reduce carbon intensity by $17 \%$ by 2015 , compared to the level of 2010, as well as the improvement of energy consumption by $16 \%$ relative to GDP $(\mathrm{Ni}, 2012)$.

The effects of these measures meant that China now plays a leading role in the production of renewable energy and the search for innovative ecological solutions (Jha, 2008). It is expected that activities in the field of renewable energy sources will be driven to create an innovative economy and an innovative society in the upcoming years. 
Despite the orientation to build a green, carbon-free economy and the funds invested in the development of alternative energy sources, mainly wind (58.5\% of the funds) and solar power (30\% of funds), it is estimated that over the next $15-20$ years, coal, natural gas and oil will remain the basic energy carriers in China. According to statistical data for $2014,66.5 \%$ of the energy still comes from coal production. Furthermore, it is expected that by 2020 China's share of global coal consumption will rise to $57 \%$ from $47 \%$ in 2010, putting the Middle Kingdom at the head of the rankings, ahead of the United States with its $28 \%$ share and Russia with an $18 \%$ share. This forces the Chinese government to modernize the coal mining industry through the introduction of new, environmentally friendly technology for mining and combustion, and by increasing the number of suppliers of crude oil and natural gas. This is reflected in China's engagement in environmental projects within the European Union countries, as well as in the United States.

Currently, China receives energy resources from all available sources, from Venezuela to Nigeria and Angola, as well as the neighboring Asian countries. Focusing on the import of shale gas, in turn, caused China to spend nearly 50 billion USD since 2008 on agreements such as mergers and acquisitions in the energy sector. It should also be noted that the share of alternative energy sources increased from 6\% in 2010 to $20 \%$ in 2014 . This reflects the changes that took place in recent years in the power industry of China, and the challenges that the country still faces (Góralczyk, 2015).

According to experts in the field of International Economic Relations, specializing in the issues of Asian countries (from universities such as: Leeds University Business School, The University of Tokyo, Gakushuin University, Seikei University and Warsaw School of Economics), the European market was a favorable one for Chinese investors from the beginning, due to the large openness of the European Union to a variety of foreign investment. The increase in foreign activity of Chinese enterprises and the inflow of Chinese capital to Europe was, however, mainly related to the implementation of China's Go Global policy, under which the Chinese government is trying to encourage domestic enterprises to undertake foreign expansion and to acquire the necessary experience in order to prepare the Chinese market for more intense competition related to the expected entry of China into the WTO. Until the introduction of the Go Global policy, China was focused on maintaining and gathering the largest resources of foreign capital in the country, while reducing investments outside the Middle Kingdom. The implementation of the policy of opening up to the world was perceived by the Chinese government as both a chance of access to knowledge and modern technologies, and thus to innovation, as well as the best way to invest the foreign currency reserves held by the Middle Kingdom.

A sign of the expansion of Chinese investment in all countries of the EU is their location in an increasing number of sectors. As seen in the analyses conducted by the American consulting firm Rhodium Group, the sector which was the subject of greatest interest to the investment of Chinese enterprises in the years 2000-2014 was the energy sector, as evidenced by the value of agreements conducted in that sector, for the sum of close to 13 billion EUR. Besides energy, Chinese companies invest mostly in the following sectors: automotive, engineering, and information and communication technologies, where China signed agreements of the following value, respectively 6 billion EUR, 4 billion EUR, and 3 billion EUR. When it comes to investments in the services sector, they are mainly focused on the transport sector, in which they allocated 2 billion EUR, 
and the sectors that generate higher added value, such as biotechnology or finance, where in the above mentioned period China invested a total of 3 billion EUR. Sectors which have quite recently become (since 2013) the focus of Chinese investors are agriculture and food, in which China invested a total of 5 billion EUR and real estate, which also included agreements in the amount of 5 billion EUR. What also needs to be emphasized is the great importance of the mining sector, which, in the above mentioned period, was one of the main directions of investment of Chinese companies (Hanemann \& Huotari, 2015).

Table 1 | Major M\&As (in terms of value) in the energy sector conducted by Chinese companies in the European market - 2005-2015 (included in the case study)

\begin{tabular}{|l|l|l|l|l|l|l|}
\hline \multicolumn{1}{|c|}{$\begin{array}{l}\text { Chinese } \\
\text { company }\end{array}$} & $\begin{array}{c}\text { European } \\
\text { company }\end{array}$ & Country & Sector & Value & $\begin{array}{l}\text { The share of Chinese } \\
\text { companies in the } \\
\text { European company } \\
\text { (\%) }\end{array}$ & Year \\
\hline $\begin{array}{l}\text { China National } \\
\text { Petroleum } \\
\text { Corporation }\end{array}$ & Eni Spa & Italy & energy & $\begin{array}{l}4,210 \text { bn } \\
\text { USD }\end{array}$ & $\begin{array}{l}28.57 \%+20 \% \text { (in } \\
\text { mining extraction) }\end{array}$ & 2013 \\
\hline $\begin{array}{l}\text { China Three } \\
\text { Gorges Corp }\end{array}$ & $\begin{array}{l}\text { Energias de } \\
\text { Portugal SA }\end{array}$ & Portugal & energy & $\begin{array}{l}3,5 \text { bn } \\
\text { USD }\end{array}$ & $\begin{array}{l}21.35 \% \text { (majority } \\
\text { stake) }\end{array}$ & 2011 \\
\hline $\begin{array}{l}\text { China } \\
\text { Investment } \\
\text { Corp }\end{array}$ & $\begin{array}{l}\text { Gas de France } \\
\text { Suez (ENGIE) }\end{array}$ & France & energy & $\begin{array}{l}3,15 \text { bn } \\
\text { USD }\end{array}$ & $\begin{array}{l}30 \%+10 \% \text { (of the } \\
\text { liquidation) }\end{array}$ & 2011 \\
\hline $\begin{array}{l}\text { China Huaneng } \\
\text { Group Corp }\end{array}$ & InterGen NV & Holland & energy & $\begin{array}{l}1,232 \text { bn } \\
\text { USD }\end{array}$ & $50 \%$ & 2010 \\
\hline Sinochem Corp & $\begin{array}{l}\text { Emerald } \\
\text { Energy PLC }\end{array}$ & $\begin{array}{l}\text { Great } \\
\text { Britain }\end{array}$ & energy & $\begin{array}{l}878,2 \text { bn } \\
\text { USD }\end{array}$ & $100 \%$ & 2009 \\
\hline
\end{tabular}

Source: Own compilation based on (Hansakul \& Levinger 2014) and self-conducted case study analysis

The energy sector is currently facing particular challenges, with societies aspiring to achieve sustainable development, which requires the use of new, environmentally friendly power generation technologies.

The analysis of major, in terms of value, agreements between Chinese and European companies over the last decade (Table 1) proves that decisions about signing agreements such as mergers and acquisitions are strongly conditioned by the adopted strategic directions of development of the companies, their desire to develop a competitive position in the market, as well as to improve their financial condition. Table 2 summarizes the premises for conducting the agreements such as mergers and acquisitions from the point of view of the Chinese and European enterprises.

The main premises of the agreement established by the China National Petroleum Corporation and Eni Spa was striving for the development of productive activities in an area particularly rich in natural gas deposits in East Africa, which was crucial for the Chinese company, given China's need for natural gas and the policy of Beijing focused on increasing domestic consumption. CNPC also focused on building a network of relations and development of cooperation with foreign partners who have the necessary know-how in the areas where Chinese companies feel deficient. 
Table 2 | Main premises for signing agreements such as mergers and acquisitions by Chinese companies and European companies

\begin{tabular}{|c|c|}
\hline For a Chinese company & For a European company \\
\hline $\begin{array}{l}\text { The pursuit of an international expansion strategy and } \\
\text { strategic development of the company } \\
\text { The desire of the company to develop/strengthen its } \\
\text { competitive position on the market } \\
\text { The desire to improve the financial condition of the } \\
\text { company } \\
\text { The need to acquire modern and environmentally friendly } \\
\text { technology } \\
\text { The pursuit of governmental policy in China focused on the } \\
\text { development of an innovative economy and an innovative } \\
\text { society } \\
\text { The desire to find a basis for sustainable development } \\
\text { The desire to develop a low carbon economy } \\
\circ \quad \text { The desire to change the image, increase the prestige and } \\
\text { visibility of the company logo } \\
\text { The chance to accelerate the internationalization process of } \\
\text { the company }\end{array}$ & $\begin{array}{l}\text { The desire to maintain/improve } \\
\text { the competitive position on the } \\
\text { market } \\
\text { The need for financial support } \\
\text { after the global crisis of 2007- } \\
2009 \\
\text { Use of the potential of Chinese } \\
\text { companies - mutual exchange of } \\
\text { benefits } \\
\text { The opportunity to increase the } \\
\text { company's market share in the } \\
\text { Chinese market } \\
\text { The desire to strengthen } \\
\text { the directions of sustainable } \\
\text { development } \\
\text { The improved prospects for } \\
\text { development in the long term }\end{array}$ \\
\hline
\end{tabular}

Source: Own compilation based on the results of case studies of selected M\&As conducted by Chinese companies on the European market between 2005 and 2015, as well as on the results of in-depth interviews conducted with experts in the field of International Economic Relations, specializing in the issues of Asian countries.

Similarly, in the case of China Three Gorges Corporation, the interest of the Chinese company in the acquisition of shares in Energias de Portugal was the only part of a larger strategy of the company's expansion into the European market and the expansion of its business into new markets in North America and Brazil. On the other hand, the main objective of the partnership between Gas de France Suez (ENGIE) and the China Investment Corp was the use of the rapidly growing demand for liquefied natural gas in Asia and establishing close contacts with energy industry stakeholders operating in the region.

Taking into account the value of the assets of the Dutch company InterGen, the Chinese investor, the China Huaneng Group Corp, saw the transaction as an opportunity to accelerate the company's internationalization process while developing the potential of the Dutch partner. The partnership between the companies was supposed to promote an increase in their ability to conduct international operations, as well as expand the energy business conducted by the companies.

In the case of agreement between the Emerald Energy PLC and Sinochem Corp, the agreement between the parties was supposed to enable the Chinese company to optimize the structure of the reserves of oil and gas, and also facilitate the strategic placement of their mining assets in South America and the Middle East in order to build a solid foundation for future growth in these areas. Despite the small size of that acquisition, its main purpose was to stimulate the mining activity of Sinochem.

The benefits of agreements such as mergers and acquisitions should be considered both from the perspective of companies initiating them, i.e. Chinese companies, as well as from the perspective of the acquired companies, in this case, the European ones. In 
addition, the analysis of the impact of mergers and acquisitions should take into account the challenges faced by businesses in today's market, as well as the intricacies of the sectors in which the agreements are made.

Table 3 | Main effects of agreements such as mergers and acquisitions conducted by Chinese companies and European companies

\begin{tabular}{|c|c|}
\hline For a Chinese company & For a European company \\
\hline $\begin{array}{l}\text { O The growth of the company's potential } \\
\text { and establishing technological and } \\
\text { research cooperation with a European } \\
\text { company } \\
\text { o The strategic transformation of the } \\
\text { company and the restructuring of its } \\
\text { business portfolio } \\
\text { o Maintenance of permanent, positive } \\
\text { growth rate } \\
\text { Improving effectiveness through } \\
\text { rationalization of production processes - } \\
\text { reducing costs } \\
\text { o Strengthening the market position of the } \\
\text { company, and even becoming the leader } \\
\text { in the industry } \\
\text { o Access to new markets and new customers } \\
\text { The implementation of environmental } \\
\text { policy and rules (increasing social } \\
\text { responsibility) } \\
\text { The ability to use new models and risk } \\
\text { management practices } \\
\text { The use of the prestige already developed } \\
\text { by a foreign company } \\
\text { The development of a new model of } \\
\text { partnership }\end{array}$ & $\begin{array}{l}\text { O Attracting Chinese strategic investors to the } \\
\text { European market } \\
\text { O Access to the Chinese market and local natural } \\
\text { resources, expanding activity to the markets in } \\
\text { the Asia-Pacific region } \\
\text { O Strengthening production potential by } \\
\text { developing technological and research } \\
\text { cooperation and implementing advanced } \\
\text { technologies } \\
\text { O Obtaining new jobs for the local population } \\
\text { O Creating opportunities for long-term } \\
\text { development of companies } \\
\text { O The strengthening of the market position and } \\
\text { competitiveness of the company } \\
\text { O Improving the efficiency of the projects and } \\
\text { production processes and strengthening the } \\
\text { financial stability of the companies } \\
\text { O Increasing the scale of investment in } \\
\text { renewable energy and achievements in } \\
\text { promoting ecological solutions } \\
\text { O The development of a new model of } \\
\text { partnership } \\
\text { Creation of new business development } \\
\text { prospects around the world }\end{array}$ \\
\hline
\end{tabular}

Source: Own compilation based on the results of case studies of selected M\&As conducted by Chinese companies on the European market between 2005 and 2015, as well as on the results of in-depth interviews conducted with experts in the field of International Economic Relations, specializing in the issues of Asian countries.

The main effects of mergers and acquisitions are presented in Table 3. Based on the analysis of five selected cases, agreements such as mergers and acquisitions made in the energy sector within the last decade reveal the following main effects of agreements between Chinese companies and their European partners. In particular, there is an emphasis on the possibility for the use of advanced technology and know-how by the Chinese companies, allowing the rationalization of production processes, which ultimately leads to lower costs.

Furthermore, foreign expansion contributes to the restructuring of the business portfolio of companies, and the increase of their potential has a positive influence on the development of cooperation with European partners. As a result, it becomes easier to identify new areas of oil and gas extraction. These benefits, observed, among others, in the case of China National Petroleum Corporation, can also be perceived in the case of 
China Three Georges, whose expansion on the European market created an opportunity for the company to establish technological cooperation and research, and the achievement of synergies with the projects carried out jointly with the European partner.

The China Investment Corporation, on the other hand, significantly improved its efficiency by an increase in investment income and total revenues, as well as in lower prices. Moreover, the company engaged in investments focused on the development of areas of renewable energy in developing countries, expressing aspirations to create a global low-carbon economy.

The result of the established agreement between Sinochem and Emerald Energy was the strengthening of the Chinese company's market position, both in the Middle East and in South America, as well as in China. Moreover, the company managed to maintain a solid positive growth rate, undergoing a transformation in key business segments, and strengthening its position in the international arena.

Finally, the acquisition of shares in InterGen by China Huaneng contributed to the internal modernization of the company and maintenance of a high level of performance of its activities, which translated into positive economic results. This, in turn, enabled the company to transform into a global leader in the industry, and implement the concept of sustainable development in the field of energy.

This direction is consistent with the objectives of the government policy in China, which focuses on the development of alternative energy sources, which are a key component of stimulating both the development of an innovative economy and an innovative society, as well as the implementation of other strategic goals of the Chinese government, challenging not only for the field of energy in China, but also for the global energy sector (Góralczyk, 2015).

In turn, looking from the perspective of European company the following effects of agreements such as, mergers and acquisitions, conducted with Chinese companies can be indicated:

- Attracting Chinese strategic investors to the European market and expanding business activities to other markets, including those in the Asia-Pacific region,

- Strengthening the production potential by developing technological cooperation and research, and by the implementation of advanced technologies,

- Improving the efficiency of the projects and production processes and strengthening the financial stability of companies,

- Increasing the scale of investment in renewable energy and achievements in promoting ecological solutions that contribute to the development of a low-carbon economy on a global scale,

- Creation of new business development prospects around the world.

\section{Conclusion}

In conclusion, it is important to emphasize the fact that the benefits of mergers and acquisitions in the energy sector are revealed in: the strategic aspect, since there is a strategic transformation of Chinese companies, as well as in the tactical aspect, expressed by the changes made in the management of companies and in the operational aspect, by the increase of the efficiency of their undertakings. 
As follows from the analysis conducted by the author on a number of agreements such as mergers and acquisitions, Chinese companies - i.e. the initiators of mergers and acquisitions - mainly expect to obtain new technologies and new concepts and management models. Thanks to these, they can modernize the system of company management and production processes. It also allows them to support the rationalization of these processes and the strengthening of the competitive market position of the companies.

A positive result of the mergers and acquisitions may be also the tendency to create attitudes of social responsibility in Chinese companies, which require the use of environmentally friendly solutions. It is consistent with their objectives related to the achievement of sustainable development.

On the other hand, European companies, participants in mergers and acquisitions, obtain obvious benefits in the opportunities of access and expansion into the Chinese market, and in particular in the access to suppliers and a rich base of raw materials. Moreover, thanks to the agreements signed with Chinese partners, European companies improve and stabilize their financial situation, which can be considered a key factor in the implementation of the adopted development strategy.

The influx of Chinese capital into markets around the world, including the European ones, plays an important role in the process of adding dynamics to the economies most affected by the financial crisis of 2007-2009. The increased activity of Chinese companies in Europe contributed not only to lower costs of infrastructure projects and the creation of new jobs, but it also created opportunities for greater and easier access to the Chinese market for local companies, and raised the profitability of research and development activities, all due to the great interest of Chinese companies in European technology (Millner, 2012). This gives hope that due to the intensification of China's international expansion and the involvement of Chinese investors in the international arena, the changes to legislation to facilitate the investments of foreign companies in the Chinese market, not only in the energy sector, will be introduced.

It is, however, important to note that the increased investment activity of Chinese companies on the European market entails a number of challenges for the markets which receive the incoming capital, not only in the economic sphere but also in the political and cultural ones. They stem from significant ideological and cultural differences, a difference in management models, and political influence on the international arena.

\section{References}

Alon, I., Fetscherin, M., \& Sardy, M. (2008). Geely Motors: A Chinese Automaker Enters International Markets. International Journal of Chinese Culture and Management, 1(4), 489-498

Andrews-Speed, P., Herberg, M. E., Zhidong, L., \& Shobert, B. (2014). China's Energy Crossroads: Forging a New Energy and Environmental Balance. NBR Reports. Retrieved September 21, 2016 from http://www.nbr.org.

Brahic, C. (2007). China's emissions may surpass the US in 2007. New Scientist, Daily News. Retrieved September 21, 2016 from http://www.newscientist.com.

Chemia Przemysłowa (2010). Chińska eksplozja energetyczna, Chemia Przemysłowa Journal. Retrieved November 2, 2015 from http://www.kierunekspozywczy.pl/ artykul,2759,chinska-eksplozja-energetyczna.html. 
Dunning, J. (1980). Towards an Eclectic Theory of International Production: Some Empirical Tests. Journal of International Business Studies, 11(1), 9-31.

Gallo, F. T. (2011). Business leadership in China. How to blend best western practices with Chinese wisdom. New York: John Wiley \& Sons.

Gonzalez, P., Vasconcellos, G. M., \& Kish, R. J. (1998). Cross-border mergers and acquisitions: the undervaluation hypothesis. The Quarterly Review of Economics and Finance, 38(1), 25-45.

Góralczyk, B. (2015). Chińskie wyzwania energetyczne. Obserwator Finansowy. Retrieved March 3, 2015 from http://www.obserwatorfinansowy.pl/forma/rotator/ chinskie-wyzwania-energetyczne/.

Hanemann, T., \& Huotari, M. (2015). Chinese FDI in Europe and Germany. Preparing for a New Era of Chinese Capital. Report prepared by Mercator Institute for China Studies and Rhodium Group. Retrieved September 21, 2016 from http://www.iberchina.org/files/ChineseFDI_ Europe_Mercator.pdf.

Hansakul, S., \& Levinger, H. (2014). China-EU relations: Gearing up for growth. Deutsche Bank Research Report Current Issues Emerging markets. Retrieved September 21, 2015 from https://www.deutsche-bank.de/fk/de/docs/China-EU-relations.pdf.

Hopkins, D. (1999). Cross-border mergers and acquisitions: Global and regional perspectives. Journal of International Management, 5(3), 207-239.

ING Report (2014). ING Corporate Finance Asia, Sino-Europe Outbound M\&A Review 1H 2014, Semi Annual Newsletter. Retrieved September 21, 2016 from http://www.ingcb.com.

ING Report (2015). ING Corporate Finance Asia, Sino-Europe Outbound M\&A Review 1H 2015, Semi Annual Newsletter. Retrieved September 21, 2016 from http://www.ingwb.com.

Jha, A. (2008). China 'leads the world' in renewable energy. The Guardian. Retrieved November 2, 2015 from https://www.theguardian.com/environment/2008/aug/01/renewableenergy. climatechange.

Millner, C. (2012). Eyes on the Price: Beijing Sets its Sights on Central Europe. Spiegel Online International. Retrieved November 2, 2015 from http://www.spiegel.de/ international/europe/with-10-billion-dollar-credit-line-china-deepens-presence-incentraleurope-a-833811.html.

Ni, V. (2012). China Sets New Greenhouse Gas Emission Reduction Goals. China Briefing. Retrieved November 2, 2015 from http://www.china-briefing.com/news/2012/01/18/china-setsnew-greenhouse-gas-emission-reduction-goals.html.

Porter, M. E. (1985). The Competitive Advantage of Nations. New York: The Free Press.

Porter, M. E. (2008). Competitive Advantage: Creating and Sustaining Superior Performance. New York: The Free Press.

Porter, M. E. (2010). Przewaga konkurencyjna. Osiąganie i utrzymywanie lepszych wyników [Competitive Advantage: Creating and Sustaining Superior Performance]. Gliwice: Helion.

Reuters (2006). China fears disasters, grain cut from global warming. Retrieved November 2, 2015 from http://www.reuters.com/article/us-china-climate/ china-fears-disasters-grain-cut-from-global-warming-idUSPEK7890420061227.

Rymarczyk, J. (2006). Międzynarodowe Stosunki Gospodarcze. Warszawa: Polskie Wydawnictwo Ekonomiczne.

Sherman, A. J., \& Hart, M. A. (2010). Mergers and Acquisitions from A to Z. New York: American Management Association. 
Sudarsanam, P. S. (2003). Creating value from mergers and acquisitions: The challenges: An integrated and international perspective. London: Pearson Education.

Sudarsanam, P. S. (1995). The essence of mergers and acquisitions. London: Prentice Hall.

Weston, F. (1992). Financial theory and corporate policy. New York: McGraw Hill.

Weston, F. (1990). Mergers, Restructuring and Corporate Control. London: Prentice Hall.

World Nuclear Association (2016). Nuclear Power in China. Retreieved September 21, 2015 from http://www.world-nuclear.org/information-library/country-profiles/countries-a-f/ china-nuclear-power.aspx.

Xinhuanet News (2007). China issues national plan to address climate change. Retrieved November 2, 2015 from http://www.fmprc.gov.cn/ce/cedk/eng/zdgx/t326940.htm.

\section{Author}

\section{Karolina Łopacińska, Ph.D.}

Assistant Professor

Department of International Economic Relations

Wrocław University of Economics

Komandorska 118/120

53-345 Wrocław, Poland

lopacinska.karolina@gmail.com 